\title{
ZNAČAJKE I TRETMAN MALOLJETNIH EKSPERIMENTATORA O PSIHOAKTIVNIM TVARIMA U TERAPIJSKOJ ZAJEDNICI
}

\author{
Chiara Cavicchi ${ }^{1}$, Dragan Babić2 , Gordana Cavicchi $^{3}$, Darjan Franjić ${ }^{4}$, Berina Hasanefendić ${ }^{5}$ \\ ${ }^{1}$ Filozofski fakultet Sveučilišta u Mostaru \\ ${ }^{2}$ Fakultet zdravstvenih studija Sveučilišta u Mostaru \\ ${ }^{3}$ Terapijska zajednica Pape Ivana XXIII, Vrgorac, Republika Hrvatska \\ ${ }^{4}$ Klinika za onkologiju, Sveučilišna klinička bolnica Mostar \\ ${ }^{5}$ Fakultet zdravstvenih studija Univerzitet u Sarajevu \\ 88000 Mostar, Bosna i Hercegovina
}

Rad je primljen 19.02.2021. Rad je recenziran 18.03.2021. Rad je prihvaćen 19.04.2021.

\section{SAŽETAK}

Maloljetnička delinkvencija upućuje na postojanje nepovoljnih socijalnih okolnosti u kojima djeca odrastaju što traži vrlo kompleksnu intervenciju usmjerenu prema brojnim faktorima koji uzrokuju takvu pojavu. Zbog nedovoljne izgrađenosti i osjetljivosti u fazi odrastanja, razvoj mlade osobe može biti usmjeren u asocijalnom ili antisocijalnom pravcu, sve do kriminalnog oblika ponašanja. Maloljetni eksperimentator predstavlja osobu koja prije nego li počne uzimati sredstvo ovisnosti već dugo nije zadovoljna svojim životom. Uzroci mogu biti različiti: od osamljenosti, zatvorenosti u sebe, nepostignutih ciljeva, dosade, frustriranosti zbog razočarenja, neprihvaćenosti u društvu. Osim toga ljudi koji ulaze u svijet ovisnosti obično nemaju obitelj u pravom smislu riječi. Često nije lako prepoznati razliku između «normalnih», uobičajenih promjena u adolescenciji, kao što su promjene raspoloženja i prkošenje roditeljima i nastavnicima i znakova zlouporabe sredstava ovisnosti. Postoji niz znakova zlouporabe sredstava ovisnosti kod mladih, a najvažniji od njih je promjena, odnosno važno je obratiti pažnju na bilo kakve značajne promjene u fizičkom izgledu, ličnosti, stavovima ili ponašanju. Terapijske zajednice tijekom zadnjih desetljeća pokušavaju dati odgovor na pojave i problematiku vezanu uz zlouporabu sredstava ovisnosti. Kod svih korisnika terapijske zajednice prisutni su problemi u ponašanju različitih oblika i intenziteta te određeni stupanj odgojno-obrazovne zapuštenosti. Svrha terapijske zajednice je psihoterapijska i rehabilitacijska. Bez adekvatne psihoterapije i socioterapije maloljetni korisnici bi postali učestali korisnici zdravstvenih službi.

Ključne riječi: maloljetni eksperimentatori; psihoaktivne tvari; terapijska zajednica

Autor za dopisivanje:

Prof. dr. sc. Dragan Babić

E-mail: dragan. babic@fzs. sum.ba 


\section{UVOD}

Maloljetnik je osoba koja nije navršila zakonom predviđenu dob za punu pravnu odgovornost i za stjecanje punih građanskih prava i građanskih dužnosti (1). U terminološkim određenjima pojedinih pojmova vezanih uz pojavu maloljetničke delinkvencije često se u literaturi i praksi primjećuje nedostatak jasnoće definicija ili njihovo nepoznavanje (2). Delinkventno ili kriminalno ponašanje mladih poseban je dio općenitijeg fenomena koji se naziva različitim izrazima (asocijalno, devijantno, problematično, antisocijalno), a najčešće se govori o „poremećajima u ponašanju“ (3). Termin poremećaji u ponašanju odnosi se na skupni naziv za različite forme neadekvatnog, društveno neprihvatljivog, štetnog i inkriminiranog ponašanja djece i mladeži. Pri tome različite vrste poremećaja u ponašanju mogu biti međusobno vrlo usko isprepletene i povezane uzrocima i posljedicama, kao i načinima interveniranja društva. U svakom slučaju, riječ je o ponašanjima kojima djeca i mladi čine određene teškoće, štete, stvaraju probleme bilo samima sebi, bilo drugoj osobi, skupini ili zajednici. Pri tome takvo ponašanje mora imati negativne reperkusije na obrazovno i radno postignuće djeteta te njegovo socijalno i ukupno ponašanje i funkcioniranje.

Poremećaji u ponašanju počinju uobičajeno kao ometajuća ponašanja u školskoj sredini ili u sredini gdje djeca provode slobodno vrijeme, s problemima $\mathrm{u}$ učenju i ponašanju u razredu, izostancima s nastave, sukobima s vršnjacima. U predadolescentnoj i adolescentnoj dobi manifestiraju se kao prkosno ponašanje, koje uključuje agresivnost prema članovima obitelji, vršnjacima i učiteljima te sklonost skitnji i bježanju od kuće. Još teži oblici poremećaja u ponašanju sadrže, osim već nabrojenih, konzumaciju alkohola i ilegalnih supstanci, što je povezano s ozbiljnim problemima u obrazovanju i nerijetko rezultira prekidom školovanja, a sve više poprima oblike kažnjivog ponašanja, što uključuje počinjenje prekršaja ili kaznenih djela (4). Asocijalno pojnašanje podrazumijeva one oblike ponašanja koji su $\mathrm{u}$ suprotnosti $\mathrm{s}$ društveno prihvaćenim normama ponašanja (njime je obuhvaćen jedan uži segment delinkvencije), ali ovakva ponašanja nisu pravno inkriminirana i sankcionirana (5). Antisocijalno ponašanje je ponašanje kojim se krše društvene norme te koje ima štetne posljedice za socijalnu okolinu, u različitoj dobi manifestira se kroz različite pojavne oblike (6). Rizično ponašanje je ponašanje koje ugrožava zdravlje i ukupno fizičko, psihičko i socijalno blagostanje pojedinca. Obuhvaća ona ponašanja koja nisu kršenje postojećih pravnih propisa ali su se pokazala kao ponašanja koja prethode delinkventnom ponašanju ili se javljaju istovremeno. Većina rizičnih ponašanja pojavljuje se kao znak socijalne neprilagođenosti, te se uglavnom odnose na rizična seksualna ponašanja, zlouporabu alkohola, zlouporabu psihoaktivnih tvari, poremećaje u prehrani (4). Socijalna neprilagođenost se pojavljuje kao reakcija na stresne događaje u životu, na promjene i traume koje mogu izazvati prolazne poremećaje, najčešće kod adolescenata, tzv. adolescentne krize. Ponekad je teško točno identificirati socijalne neprilagođenosti i adolescentne krize jer je teško utvrditi jesu li određene pojave $u$ adolescenciji normativna razvojna kriza ili je riječ o pojavi koja izlazi iz normativnih okvira (7).

\section{Maloljetnička delikvencija}

Usko shvaćanje pojma maloljetnička delinkvencija obuhvaća sva ponašanja maloljetnika koja su inkriminirana u pozitivnom zakonodavstvu, uz uvažavanje načela zakonitosti. To su ona ponašanja koja sukladno zakonu imaju elemente kaznenih djela. Šire shvaćanje pojma maloljetničke delinkvencije obuhvaća sva ponašanja koja znače kršenje nekog pravnog propisa. Navedeno se odnosi na kaznena djela i sva druga ponašanja koja su u suprotnosti $\mathrm{s}$ bilo kojom pravnom normom u zemlji. Najšire shvaćanje maloljetničke delinkvencije podrazumijeva ponašanja, situacije i stanja maloljetnika koja odstupaju od normalnog ili se smatraju nepoželjnim i štetnim. Time se maloljetnička delinkvencija poistovjećuje s odgojnom zapuštenosti i društvenom neprilagođenosti maloljetnika. To znači proširenje pojma maloljetničke delinkvencije na razna preddelinkventna stanja (npr. bježanje od kuće, među vršnjačko nasilje, konzumacija alkohola i opojnih sredstava) koja pogoduju kršenju pravnih normi. Maloljetnička delinkvencija upućuje na postojanje nepovoljnih socijalnih okolnosti u kojima djeca odrastaju što traži vrlo kompleksnu intervenciju usmjerenu prema brojnim faktorima koji uzrokuju 
takvu pojavu. Zbog nedovoljne izgrađenosti i osjetljivosti u fazi odrastanja, razvoj mlade osobe može biti usmjeren $\mathrm{u}$ asocijalnom ili antisocijalnom pravcu, sve do kriminalnog oblika ponašanja (8).

Psiholozi u rizične faktore za razvoj ozbiljne i trajne delinkventne aktivnosti svrstavaju psihološke i neurološke faktore, kognitivne faktore (niži IQ, slabija koncentracija i pažnja, slabije apstraktno rasuđivanje i sl. ), hiperaktivnost (impulzivnost, niska tolerancija na frustraciju), obiteljske faktore (odbijanje roditelja, slabo roditeljsko uključivanje, alkoholizam i kriminal roditelja, razdvojenost obitelji i razvod roditelja), utjecaj vršnjaka (delinkventno ponašanje, različiti poremećaji u ponašanju) i utjecaj škole (loš školski uspjeh, loša školska klima, nezainteresiranost nastavnika, problemi u ponašanju). Zbog toga psihološki i psihijatrijski aspekt procjene maloljetnika može pomoći u predviđanju delinkvencije i recidivizma (9).

Rezultati istraživanja koja su provele Cajner i suradnici2002. godine ukazuju na to da u obiteljskim prilikama maloljetnih delinkvenata na području grada Zagreba koji su skloni agresivnim modelima ponašanja i onih koji to nisu postoji razlika tako da su nepovoljna odgojna situacija u obitelji i niži ekonomski status obitelji, te niža školska sprema majke više u vezi s onim ispitanicima koji su skloni agresivnim modelima ponašanja (10).

Najveći broj istraživanja ipak ukazuje na to da se materijalnim uvjetima ne može pripisivati odlučujuće značenje u određivanju prijestupništva mladih, ali se može pretpostaviti povezanost nesređenih odnosa u obitelji s nepovoljnim prihodima tih obitelji. Istraživanja pokazuju da $34 \%$ maloljetnih delinkvenata potječe iz obitelji sa slabim ili vrlo slabim ekonomskim statusom, a $60 \%$ iz obitelji prosječnog ekonomskog statusa (Singer i suradnici, 2008). Također, emocionalni i/ili psihički problemi roditelja su često identificirani kao rizični faktori za rast i razvoj mladih. Takvi roditelji često zanemaruju svoje obaveze, nedosljedni su u odgojnim postupcima, ne znaju pokazati ljubav i razumijevanje, ne znaju komunicirati i nadzirati dijete (9). Nadalje, utvrđena je značajna veza između lošeg obiteljskog funkcioniranja (svađe, fizičko nasilje, zlostavljanje) i niskog stupnja socijalizacije kod adolescenata, uključujući agresivnost i dislociranost. Zaštitni faktori vezani uz obiteljske odnose kao što su emocionalna bliskost, čvrstoća obitelji, obiteljsko vrijeme i rutine, uvažavanje obiteljske tradicije su važni jer će u takvom okruženju dijete biti privrženo roditelju, usvajat će pozitivne vrijednosti i roditelji će mu biti pozitivan model identifikacije (11).

\section{Maloljetnici eksperimentatori}

Fokus programa rada s maloljetnicima u terapijskoj zajednici je maloljetna osoba koja je na umjetan način počela podmirivati svoje potrebe i koja polako gubi ili je već izgubila kontrolu nad drugim mogućnostima izbora. Brojne teorije bave se uzrocima zlouporabe i ovisnosti o psihoaktivnim tvarima. Jedne govore da je to posljedica jačanja međunarodnog narko kriminala, druge smatraju da je uzrok u promijenjenoj kvaliteti života ljudi, gdje je čovjek uz brz tehnički napredak stvorio i niz poteškoća koje su se negativno odrazile na kvalitetu međuljudskih odnosa, što za posljedicu ima sve veće nezadovoljstvo ljudi i osjećaj bezperspektivnosti (12). Maloljetni eksperimentator predstavlja osobu koja prije nego li počne uzimati sredstvo ovisnosti već dugo nije zadovoljna svojim životom. Uzroci mogu biti različiti: od osamljenosti, zatvorenosti u sebe, nepostignutih ciljeva, dosade, frustriranosti zbog razočarenja, neprihvaćenosti u društvu. Osim toga ljudi koji ulaze $\mathrm{u}$ svijet ovisnosti obično nemaju obitelj u pravom smislu riječi (13).

\section{Osobine maloljetnika konzumenata sredstava ovisnosti}

Često nije lako prepoznati razliku između «normalnih», uobičajenih promjena u adolescenciji, kao što su promjene raspoloženja i prkošenje roditeljima i nastavnicima i znakova zlouporabe sredstava ovisnosti. Postoji niz znakova zlouporabe sredstava ovisnosti kod mladih, a najvažniji od njih je promjena, odnosno važno je obratiti pažnju na bilo kakve značajne promjene u fizičkom izgledu, ličnosti, stavovima ili ponašanju. Znakovi zlouporabe sredstava ovisnosti na koje posebno treba obratiti pažnju kod adolescenata su sljedeći:

- Zanemarivanje obveza u školi ili kod kuće;

- Promjene u fizičkom izgledu;

- Problemi u socijalnim odnosima;

- Ulaženje u rizike; 
- Pojačano trošenje novca;

- Problemi sa zakonom.

Važno je poznavati znakove i simptome zlouporabe sredstava ovisnosti kako bi se ona što ranije prepoznala. Tu posebno važnu ulogu imaju osobe koje su s adolescentima u svakodnevnom kontaktu - roditelji, nastavnici, školski psiholozi i pedagozi, školski liječnik. Ranim prepoznavanjem zlouporabe sredstava ovisnosti povećava se vjerojatnost za pravovremenu intervenciju odnosno poduzimanje odgovarajućih mjera sprječavanja daljnje zlouporabe i razvoja ovisnosti (13).

\section{Terapijska zajednica}

Ideja terapijske zajednice potekla je iz religijskih i političkih pokreta kao što su ideje Tukesa i «moralnog liječenja» s početka 19. stoljeća. Model poznat kao «moralno liječenje» isticao je važnost rada, zdrave okoline i podržavajućih odnosa, a snažno je utjecao na stvaranje azila u Velikoj Britaniji i SAD-u u prvoj polovini 19. stoljeća. Početkom 20. stoljeća, pioniri terapijske edukacije, inspirirani kršćanskim vjerovanjem u terapijsku snagu ljubavi i Freudovom novom metodom psihoanalize, stvorili su rezidencijalne škole za maladaptiranu djecu (14).

Opći cilj u radu s maloljetnicima u tretmanu je adaptacija i potpuna integracija u širu društvenu sredinu, uspješan nastavak školovanja, te usvajanje društveno-prihvatljivog modela ponašanja. Specifični ciljevi su slijedeći:

- Modifikacija ponašanja, odnosno razvijanje pozitivnog modela ponašanja;

- Razvijanje osobne odgovornosti;

- Pojačan utjecaj na odustajanje od daljnjeg činjenja kaznenih djela (u slučaju kada su postojala ranije);

- Pojačani utjecaj na usvajanje i poštivanje zakonskih normi;

- Razvijanje pozitivnog odnosa prema učenju;

- Usvajanje pozitivnih društvenih vrijednosti;

- Razvijanje pozitivnih interesa i navika;

- Strukturiranje i razvijanje koncepta konstruktivnog provođenja slobodnog vremena;

- Prevladavanje odgojno-obrazovnih teškoća;

- Prevladavanje teškoća socijalne integracije u užoj i široj sredini;

- Postizanje osobne, obrazovne, socijalne pozitivne afirmacije (15).
Terapijske zajednice tijekom zadnjih desetljeća pokušavaju dati odgovor na pojave i problematiku vezanu uz zlouporabu sredstava ovisnosti. Unutar terapijske zajednice koriste se različiti instrumenti: od medicinskog pristupa do individualnih i grupnih psiholoških dinamika s neposrednim iskustvima suživota, usmjeravanja prema vrijednostima i iskustvima duhovnog djelovanja, te priznatim sredstvima $u$ postupku mijenjanja načina ponašanja, osjećaja i socijalizacije. Terapijska zajednica je izvaninstitucionalni oblik psihosocijalnog tretmana i pružanja pomoći ovisnicima i maloljetnim eksperimentatorima (korisnici) tijekom određenog vremenskog razdoblja, unutar kojeg se koriste metode rada terapijske zajednice zasnovane na hijerarhiji, precizno strukturiranom programu s jasno definiranim principima povlastica i ograničenja, te promoviranju metode samopomoći odnosno aktivnog sudjelovanja korisnika u terapijskom programu. U okviru terapijskog programa pruža socijalnu terapiju, provodi radnu terapiju i radno - okupacijske aktivnosti, brine o zdravlju korisnika i organiziranju korištenja zdravstvenih usluga. Također vrši edukacije ovisnika i maloljetnih eksperimentatora radi prevencije recidiva i sprječavanja zaraznih bolesti, te pruža psihološku podršku kroz individualni i grupni rad s korisnikom i obitelji korisnika.

Glavna obilježja terapijskog rada s maloljetnicima koja doprinose efikasnosti tretmana su individualni i multidisciplinarni pristup, a tretman provode stručnjaci različitih profila: psiholozi, socijalni radnici, socijalni pedagozi a po potrebi pravnici i psihijatri. Metode rada koje se koriste prilikom provođenja tretmana su metode razumijevanja, nametanja, podučavanja, uvjeravanja, usmjeravanja, poticanja i savjetovanja (16).

\section{Osobine maloljetnika - korisnika terapijske zajednice}

U tretmanu maloljetnika važno je voditi se ovim biološkim ograničenjem u trenutcima kada im se daje sloboda i odgovornost, te kada se koristi sustav nagrada i kazni u oblikovanju ponašanja. Kod svih korisnika terapijske zajednice prisutni su problemi u ponašanju različitih oblika i intenziteta te određeni stupanj odgojno-obrazovne zapuštenosti. U kontekstu složenosti zamjetna je kompleksnost 
obiteljskih prilika, od uvjeta stanovanja do odnosa među članovima obitelji, stila odgoja, a čemu pridonosi izražena rizičnost roditelja i članova uže i šire obitelji. Kompleksnost rizika u odnosu na korisnike očituje se u istodobnoj prisutnosti eksternaliziranih i internaliziranih problema u ponašanju te problema s mentalnim zdravljem. Problemi mentalnog zdravlja ističu se kroz izrazite emocionalne složenosti poput labilnosti, naglih promjena raspoloženja, te nošenja s mnogim teškim osjećajima poput tuge, odbačenosti i neprihvaćenosti. U većini slučajeva odnosi i ključne osobe u životima maloljetnika modeliraju neprihvatljiva i rizična ponašanja. Kod korisnika su najčešće dijagnosticirane kombinirane smetnje na području obrazovanja, bio-psiho-socijalnog funkcioniranja i problem socijalizacije (15).

Specifično za maloljetnike u odnosu na odrasle korisnike jest poticanje redovitijeg kontakta s obitelji od samog početka tretmana, intenzivniji rad $s$ roditeljima koji i dalje donose odluke za svoje dijete, obavezno uključivanje u obrazovni program te učestaliji individualni terapijski tretman internaliziranih problema (17).

\section{Program tretmana maloljetnika u terapijskoj zajednici}

Cjelokupna organizacija rada i života korisnika u terapijskoj zajednici organizirana je tako da se omogući podmirenje temeljnih potreba svakog korisnika, te da se stvori ugodna i poticajna atmosfera unutar koje će korisnici biti potaknuti na samostalno podmirivanje osobnih potreba na društveno prihvatljiv način (18). Svrha smještaja maloljetnika u tretman je vršenje snažnog utjecaja na maloljetnika koji se nalazi na smještaju u strogo strukturiranim uvjetima kako bi promijenio neadekvatne obrasce ponašanja u adekvatne. Ishodi koji se očekivaju od korisnika terapijske zajednice po završetku tretmana su slijedeći:

- Naučeni zdravi obrasci ponašanja;

- Razvijena odgovornost;

- Podignuta razina samopouzdanja i samopoštovanja;

- Promijenjen stav prema konzumiranju psihoaktivnih tvari;

- Usvojen konstruktivan način rješavanja problema;
- Razvijena svjesnost o zabludama (najčešće o psihoaktivnim tvarima, nerijetko i o drugim problemima);

- Postignuta trajna apstinencija.

Tretman se provodi kroz tri faze, nemoguće je odrediti točno trajanje faza budući da se svakom od korisnika pristupa individualizirano. U radu s korisnicima u Terapijskoj zajednici poštivaju se načela rada s maloljetnicima:

1. Načelo timskog rada - podrazumijeva suradnju stručnjaka različitog profila kako bi se osigurala racionalnija organizacija rada, kvalitetnije planiranje i programiranje rada i evaluacija postignuća.

2. Načelo organiziranosti/obiteljski tip - podrazumijeva prihvaćanje i njegovanje prijateljskih odnosa s članovima odgojne skupine s ciljem osiguravanja njihove sigurnosti i zaštite, razumijevanja i poštivanja dostojanstva i privatnosti.

3. Načelo socijalizacije - podrazumijeva poticanje individualne i grupne odgovornosti u uvjetima zajedničkog života u odgojnoj grupi, primjereno individualnim mogućnostima prihvaćanja i poštivanja grupnih normi, te usklađivanja osobnih i društvenih interesa.

4. Načelo aktivnosti- podrazumijeva aktiviranje i aktivno sudjelovanje svakog korisnika u terapijskoj zajednici s ciljem usvajanja znanja, stavova i uvjerenja.

5. Načelo pozitivne orijentacije - podrazumijeva zasnivanje odgojnog rada na prepoznavanju i podržavanju pozitivnih osobina i pomaka korisnika, poštivanju njihove osobnosti, održavanju povjerenja u odgojnom radu, kao i dosljednost u izvršavanju obveza.

6. Načelo samozbrinjavanja - podrazumijeva odgovornost u skrbi za osobnu higijenu, osobne predmete, urednost prostora terapijske zajednice, kao i obvezu poštivanja kućnog reda i dogovorenih pravila, a čime preuzimaju aktivnu ulogu suodlučivanja i razvijanja osobne odgovornosti.

7. Načelo individualizacije - podrazumijeva primjenu onih zadataka, sredstava, oblika i metoda odgojnog rada koji će temeljem prepoznavanja maloljetnika, mogućnosti i sposobnosti 
u svakom konkretnom slučaju omogućiti postizanje mogućih rezultata (15).

\section{Proces realizacije smještaja maloljetnika u terapijsku zajednicu}

Proces realizacije smještaja maloljetnika $u$ terapijsku zajednicu odvija se kroz tri faze, odnosno pripremnu fazu, savjetodavni rad i prijem. U pripremnoj fazi stručni djelatnici Zajednice, pregledavaju zaprimljeni pismeni zahtjev, te unaprijed prikupljaju svu potrebnu dokumentaciju, poput socijalne anamneze, zdravstvene dokumentacije, osobne dokumentacije, obavljaju dodatne razgovore sa stručnim djelatnicima koji su upoznati s problematikom korisnika. Svrha savjetodavnog rada je pružiti podršku i pomoć pojedincu na putu promjene. Iako je $\mathrm{u}$ fokusu rada pojedinac nerijetko su u proces savjetovanja uključeni članovi uže obitelji, ponekad se provodi grupni rad sa svim članovima uključenim u jedan proces kako bi se osnažila dinamika obiteljskih odnosa i osvijestila odgovornost za promjenu svakog pojedinog člana. Završetak procesa savjetovanja može biti uzrokovan odustajanjem korisnika, prekidom rada voditelja savjetovanja uz upućivanje korisnika na drugi oblik pomoći ili redovnim završetkom procesa savjetovanja uz ispunjene zadane ciljeve (17). Savjetodavni rad kao jedan dio programa može imati značajan utjecaj na razvoj osjećaja samoefikasnosti i odgovornosti. Korisnika se u ovoj fazi nastoji potaknuti na prihvaćanje smještaja kao alata za postizanjem osobnih ciljeva (završavanje obrazovanja, razvoj zdravih životnih navika, stjecanje raznih vještina, poboljšanje obiteljskih odnosa i slično). Pregledom sve dostavljene dokumentacije i postavljanjem specifičnosti maloljetnika u kontekst trenutnih korisnika u terapijskoj zajednici, te predviđajući mogućnosti napretka stručni tim donosi odluku o prijemu. Tijekom postupka prijema vodi se kratki informativni razgovor s obitelji i stručnim djelatnicima, razmjenjuju se informacije o terminima posjeta i poziva, kontakt brojevi, posljednji medicinski nalazi, preuzima se farmakoterapija ako je ista propisana maloljetniku, te se još jednom potvrđuje kontakt broj, ime i prezime nadležnog liječnika. Provodi se kratak razgovor s maloljetnikom, pri čemu se ispunjava osobni list korisnika, potpisuje izjavu o suglasnosti za korištenje osobnih podataka, potpisuje ugovor o međusobnim odnosima, te izjavu o pohranjenim osobnim predmetima (15).

\section{Prihvat}

Prva faza, često prediktivna za ishod ima za cilj adaptaciju korisnika aktualnoj situaciji. Prihvat traje ovisno od osobe, tijekom ove faze traži se od korisnika poštivanje normi, a stručni tim koji se sastoji od socijalnih radnika, asistenata u terapijskoj zajednici i psihologa vrši monitoring njegovog cjelokupnog ponašanja: osjećaja, mišljenja i djelovanja. Procjenjuju se potrebe, svijet kvalitete i ponašanje korisnika (19). U fazi prihvata izrađuje se individualni terapijski plan. Na temelju dijagnostičke obrade, socijalno anamnestičkih podataka i uočenog ponašanja korisnika bilježe se uočeni rizični i zaštitni faktori koji predstavljaju osnovu za izradu individualnog plana tretmana (20). U drugoj fazi se različitim tehnikama uči podmirivanje potreba zdravim i djelotvornim metodama. Ovu fazu karakterizira niz psihosocijalnih intervencija putem kojih se postižu konkretne promjene u ponašanju maloljetnika(15).

\section{Učinkovite psihosocijalne intervencije}

Psihosocijalne intervencije su obvezni, redoviti dio tretmana, utemeljene su na procjeni psihičkog statusa i socijalnog funkcioniranja osobe. Psihološke intervencije koje su se pokazale učinkovite prema osobama koje zlouporabe sredstva ovisnosti, pa tako i prema maloljetnicima su: motivacijski intervju, CM (engl. Contingency Management) tretmanu ponašanja, različiti oblici savjetovanja, psihoedukacija, analiza i rad na slučaju, prevencija relapsa i trening životnih vještina, te primjena različitih oblika psihoterapije (21).

Motivacijski intervjuje početna intervencija s kojom počinje svaki tretman. Važan je u prevladavanju ambivalencije prema promjeni jer bez toga, osoba teško može napredovati.

Ideja CM pristupa polazi od pretpostavki psihologije učenja, točnije, instrumentalnog učenja, a to jest kako će se ponašanje koje je dozvoljeno pojavljivati češće, a ono kažnjeno manje (22).

Trening životnih vještina ukazuje na to da su socijalna ponašanja vještine koje se uče i vježbaju (23). Iako model treninga socijalnih vještina ima svoj povijesni razvoj, ono što ga čini specifičnim je 
strukturirano učenje. Strukturirano učenje je metoda u kojoj se usvajaju prethodno definirani sadržaji imajući za cilj učenje specifičnih prosocijalnih ponašanja (24). Trening životnih vještina najčešće se odvija kroz edukativno interaktivne radionice, a naučeno potkrepljuje u svakodnevnim situacijama. Od važnih vještina za adolescente ističu se kontrola emocija (učenje adaptivnih reakcija na neugodne emocije), komunikacijske vještine, posebice trening asertivnosti, organizacijske vještine, vještine rješavanja problema, razvijanje kritičkog mišljenja i samokritičnosti (25).

Radna terapija omogućuje razvoj radnih navika, odgovornosti kao i razvoj praktičnih vještina. Iako se provodi tijekom svih faza boravka, ima najvažniju ulogu u procesu resocijalizacije gdje se radna terapija češće odvija van terapijske zajednice i u kontaktu s drugim ljudima. Kroz radnu terapiju korisnici imaju priliku uvježbati novostečene socijalne vještine (26).

\section{Resocijalizacija}

U fazu resocijalizacije osoba prelazi nakon vrednovanja od strane stručnog tima u pogledu spremnosti na odabire manje rizičnih ponašanja. Prelazak u tu fazu korisniku daje osjećaj napretka i dinamičnosti. Za izlazak iz terapijskog programa detaljno se priprema i organizira, te je dopušteno korisniku više slobode i inicijative. U posljednjoj fazi maloljetnici imaju veću kontrolu nad slobodnim vremenom jer se nastoje osigurati uvjeti što sličniji onima koji ih očekuju po izlasku. Maloljetnici u ovoj fazi imaju više slobode glede samostalnog kretanja, češće odlaze u posjet obitelji i rodbini, ti posjeti postaju sve dulji. Ako maloljetnik svoje ponašanje po povratku promijeni na bolje, to upućuje na veću spremnost za povratak u društvo. Budući da je maloljetna osoba stekla vještinu samokontrole vlastitog ponašanja i nije vođena trenutnim podmirenjem svojih potreba. Nadalje, spomenuto je kako ponašanje maloljetnika nakon dužeg boravka u obiteljskoj sredini može ukazivati na to je li prilagođena maloljetnoj osobi. Ponekad, ako se radi o destruktivnim obiteljima, maloljetnik može zaključiti kako to nije sredina u koju se želi vratiti. Tada se intenzivira rad s obitelji i maloljetniku se pruža mogućnost duljeg boravka u terapijskoj zajednici ili u suradnji s drugim dionicima planira se alternativni smještaj (organizi- rano stanovanje, Dom za djecu i slično). Ovisno o ispunjenju postavljenih ciljeva na početku i tijekom tretmana, stručni tim razmatra mogućnost prekida tretmana i početak pripreme korisnika za otpust. Prilikom otpusta korisniku se naglašava da je stručni tim uvijek tu za njega, te kako se može obratiti djelatnicima tima u svakom trenutku. Stručni tim nastavlja biti podrška korisniku nakon otpusta (15).

\section{Stručni tim terapijske zajednice}

Stručni tim u terapijskoj zajednici sastoji se od pet članova poželjno različitih struka: socijalnih radnika, psihologa i socijalnog pedagoga. Socijalni radnik/radnica je osoba koja uspostavlja prvi kontakt s korisnikom. Posebnu pažnju usmjerava u komunikaciju s korisnicima koji dolaze prvi put i kojima je uglavnom potrebno vremena i snage za odluku da potraže stručnu pomoć. Rad socijalnog radnika s korisnicima provodi se kroz individualne i grupne razgovore i radionice. Kako bi stručni tim i pristup rada s maloljetnicima bio potpun potrebna je suradnja psihijatra. Prilikom prvog kontakta u savjetovalištu, korisnik se upućuje na pregled kod psihijatra.

Psihijatar je osoba koja daje stručno mišljenje o maloljetniku, a odnosi se na njegovo psihičko stanje, te preporuka za ulazak u terapijsku zajednici. Budući da su maloljetnici eksperimentatori nije im potreban psihijatar za tretman ovisničkog ponašanja. Psihijatar je važan dio stručnog tima, te ostali članovi stručnog tima nerijetko kontaktiraju istog $s$ obzirom na psihičko stanje korisnika.

Psiholog u terapijskoj zajednici ima nekoliko osnovnih zadaća: psihološko testiranje, savjetodavni rad, psihoterapijski rad, provođenje interaktivnih radionica, osmišljavanje praćenje i prilagodba individualnog plana tretmana s ostalim članovima stručnog tima, savjetodavni i psihoterapijski rad $s$ roditeljima maloljetnika. Svrha psihologa u terapijskoj zajednici je osigurati u stručnom timu psihološku perspektivu koja svoju značajnu ulogu ima upravo kod psihološkog testiranja korisnika. Psiholog sudjeluje u psihodijagnostici, pokušava utvrditi uzroke nastanka i razvoja poteškoća, utvrđuje stupanj ugroženosti i moguće posljedice (15).

Problem ovisnosti je sve aktualniji te su i na našem fakultetu provedena brojna istraživanja, a neka su objavljena i u našem časopisu Zdravstveni gla- 
snik. Jakešević i Martinac u radu iz 2015. godine navode da je zlouporaba psihoaktivnih tvari, kao što su marihuana i hašiš, povezana sa obiteljskim i društvenim odnosom, ali se povezanost sa školskim sustavom nije mogla dokazati (27). Batori i suradnici u radu objavljenom 2018. godine ističu korisnosti povezane s uporabom kanabisa (28). U istraživanju iz 2019. godine koje su proveli Bošnjak i suradnici dokazana je statistički značajna povezanost između uspjeha u školi i rizičnog ponašanja u odnosu na uporabu psihoaktivnih tvari među učenicima srednje škole (29). Janjić i suradnici su 2019. godine proveli studiju u kojoj su istraženi kvaliteta života i psihički simptomi ovisnika o opijatima (30). Janjić i Babić su 2020. godine proveli studiju u kojoj je ispitana pojavnost uporabe psihoaktivnih tvari studenata Fakulteta zdravstvenih studija Sveučilišsta u Mostaru. Njihovi rezultati pokazuju da studenti statistički značajno više puše cigarete od učenika, a da su učenici statistički značajno više udisali ljepila iostala otapala od studenata (31).

\section{ZAKLJUČAK}

Maloljetnici su kategorija korisnika koja je nepredvidiva, djelom zbog stupnja njihovog razvoja i svih promjena koje nosi adolescencija potaknuto dodatno $\mathrm{s}$ razvijenim problemima u ponašanju. Često je riječ o maloljetnicima koji imaju razvijene zdravstvene poteškoće, bivali su hospitalizirani i u psihijatrijskom tretmanu. Navedeno čini rad s maloljetnicima kompleksnim, te je važno imati na umu izvanredne hitne situacije i stanja u kojima je najvažnija pravovremena intervencija. Država i društvo u cjelini će u budućnosti trebati ulagati više ljudskih i financijskih resursa u prevenciju. Maloljetnička populacija je specifična s obzirom na svoj tjelesni, kognitivni i socioemocionalni razvoj, stoga članovi stručnog tima trebaju kontinuirano usvajati znanja i vještine koje će im omogućavati profesionalnost $u$ radu i pomoći da idu „u korak s vremenom“. Svrha terapijske zajednice je psihoterapijska i rehabilitacijska. Bez adekvatne psihoterapije i socioterapije maloljetni korisnici bi postali učestali korisnici zdravstvenih službi. Terapijske zajednice imaju važnu ulogu i važni su partneri službi za mentalno zdravlje.

\section{REFERENCE}

1. Zakon o sudovima za mladež, NN, br. 56/15.

2. Carić, A. Mlađe osobe u kaznenom pravu: (počinitelji i žrtve); odabrana poglavlja. Zagreb. Pravni fakultet, Poslijediplomski studij iz Kaznenopravnih znanosti, 2002.

3. Singer M. Kriminološke osobitosti maloljetničke delikvencije: tijek školovanja, poremećaji u ponašanju, obiteljske prilike. Zagreb: Nakladni zavod Globus; 2008.

4. Bašić J, Koller-Trbović N, Uzelac S. Poremećaji u ponašanju i rizična ponašanja: pristupi i pojmovna određenja. Zagreb: Edukacijsko-rehabilitacijski fakultet Sveučilišta; 2004.

5. Martinjak D, Odeljan R. Etiološki i fenomenološki čimbenici maloljetničke delikvencije. Zagreb: Ministarstvo unutarnjih poslova Republike Hrvatske; 2006.

6. Farington DP, West DJ. The Cambridge Study in delinquent behaviour: A long term follow - up of 411 London males. In: Kerner HJ, Kaiser G, editors. Kriminalität: Persönlichkeit, Lebensgeschichte und Verhalten. 1st ed. Berlin: Springer, Heidelberg; 1990. p. 115138.

7. Zrilić S. Povezanost bježanja s nastave i maloljetničke delikvencije. Magistra Iadertina [Internet]. 2011 [pristupljeno 17. 04. 2021. ]; 6. (1. ): 71-81. Dostupno na: https: //hrcak. srce. $\mathrm{hr} / 8733$

8. Bouillet D. Izazovi integriranog odgoja. Zagreb: Školska knjiga; 2010.

9. Stašević I, Derk D. Osobitosti maloljetničke delinkvencije u Republici Hrvatskoj. Policija i sigurnost [Internet]. 2016 [pristupljeno 17. 04. 2021. ]; 25(3): 259-275. Dostupno na: https: //hrcak. srce. hr/168474

10. Cajner Mraović I, Došen A. Obiteljske prilike i agresivni poremećaji u ponašanju maloljetnih nasilnih delinkvenata u Zagrebu. Ljetopis socijalnog rada [Internet]. 2002 [pristupljeno 17. 04. 2021. ]; 9(2): 233-248. Dostupno na: https: //hrcak. srce. hr/3522

11. Ricijaš N. Atribuiranje vlastitog delikventnog ponašanja nisko rizičnih i visoko rizičnih maloljetnih delikvenata. Kriminologija \& socijalna integracija [Internet]. 2009 [pristupl- 
jeno 17. 04. 2021. ]; 17(1): 13-26. Dostupno na: https: //hrcak. srce. hr/40730

12. Babić D. Psihoaktivne tvari. Mostar: Sveučilište u Mostaru; 2015.

13. Štimac Grbić D, Glavak-Tkalić R. Uporaba sredstava ovisnosti u općoj populaciji Republike Hrvatske: 2019. i analiza trendova uporabe 2011. -2019. Zagreb: Hrvatski zavod za javno zdravstvo i Institut društvenih znanosti Ivo Pilar; 2020.

14. Štrkalj-Ivezić S, Jendričko T, Pisk Z, Martić-Biočina S. Terapijska zajednica. Socijalna psihijatrija [Internet]. 2014 [pristupljeno 17. 04. 2021. ]; 42(3): 172-179. Dostupno na: https: //hrcak. srce. hr/134763

15. Cavicchi G, Grgurinović M, Ramić M. Maloljetnici u terapijskoj zajednici. Sempre, Rimini, 9-45.

16. Ministarstvo zdravlja [Internet]. Zagreb: Narodne novine; c2010 [citirano 16.4.2021]. Dostupno na: https: //narodne-novine. nn. hr/clanci/sluzbeni/2010_02_19_455. html

17. Ratkajec-Gašević G, Žižak A. Motivacijski mehanizmi koji prethode odluci o promjeni ponašanja kod mladih počinitelja kaznenih i prekršajnih djela. Ljetopis socijalnog rada [Internet]. 2016 [pristupljeno 17. 04. 2021. ]; 23(1): 39-64. https: //doi. org/10. 3935/ljsr. v23i1. 74

18. Hećimović V. Terapijska zajednica. Zagreb: USIZ socijalne zaštite Grada Zagreba, i Zavod Grada Zagreba za socijalni rad; 1987.

19. ISO 9000. Sustavi upravljanja kvalitetom Temeljna načela i terminološki rječnik. Zagreb; 2015.

20. Bijedić M., Kovačević R, Kuralić-Čišić L, Muftić E, Husić D. Procjena i tretman maloljetnika prilikom izvršenja sankcije. Tuzla: Off-Set; 2017.

21. EMCDDA. Smjernice za psihosocijalni tretman ovisnosti o drogama u zdravstvenom, socijalnom i zatvorskom sustavu. Zagreb: Vlada Republike Hrvatske; 2014.

22. Tatulović-Vorkapić S. Razvojna psihologija. Rijeka: Učiteljski fakultet; 2013.
23. Ferić M, Kranželić Tavra V. Trening socijalnih vještina - planiranje, priprema i evaluacija. Kriminologija \& socijalna integracija [Internet]. 2003 [pristupljeno 17. 04. 2021. ]; 11(2): 143-150. Dostupno na: https: //hrcak. srce. $\mathrm{hr} / 99011$

24. Ajduković M, Pećnik N. Nenasilno rješavanje sukoba. Zagreb: Alinea; 2007.

25. EMCDDA. European drug prevention quality standards: quick guide. Lisabon; 2013.

26. Šimunović D, Havelka-Meštrović A, Njegovan Zvonarević T. Radna terapija u prevenciji ovisnosti o psihoaktivnim tvarima. Zagreb: Hrvatski kongres preventivne medicine i unapređenja zdravlja s međunarodnim sudjelovanjem Ministarstvo zdravstva i socijalne skrbi Republike Hrvatske; Knjiga Sažetaka 2., 131-131.

27. Jakešević A, Martinac M. Prevalencija zlouporabe marihuane i hašiša među učenicima srednjih škola u Jajcu. Zdravstveni glasnik [Internet]. 2015 [pristupljeno 15. 04. 2021. ]; 1: 25-36.

28. Batori M, Žerovnik A, Barać K, Babić D. Pozitivni učinci kanabisa na zdravlje. Zdravstveni glasnik [Internet]. 2018 [pristupljeno 16. 04. 2021]; 2: 50-59.

29. Bošnjak M, Mandić K, Babić D. Prevalence of psychoactive substance use among students of Secondary Medical School "the Sisters of Mercy" in Mostar. Zdravstveni glasnik [Internet]. 2019 [pristupljeno 17. 04. 2021. ]; 5(1): 24-32.

30. Janjić M, Barać K, Grbavac K, Grbavac V, Babić R, Martinac M i sur. Kvaliteta života i psihički simptomi ovisnika o opijatima. Zdravstveni glasnik [Internet]. 2019 [pristupljeno 17. 04. 2021. ]; 5(2): 36-44.

31. Marić J, Babić D. Pojavnost uporabe psihoaktivnih tvari studenata Fakulteta zdravstvenih studija Sveučilišta u Mostaru. Zdravstveni glasnik. 2020; 6(1): 33-41. 


\title{
CHARACTERISTICS AND TREATMENT OF JUVENILE EXPERIMENTERS WITH PSYCHOACTIVE SUBSTANCES IN THE THERAPEUTIC COMMUNITY
}

\author{
Chiara Cavicchi ${ }^{1}$, Dragan Babić ${ }^{2}$, Gordana Cavicchi ${ }^{3}$, Darjan Franjić ${ }^{4}$, Berina Hasanefendić ${ }^{5}$ \\ ${ }^{1}$ Faculty of Humanities and Social Sciences University of Mostar \\ ${ }^{2}$ Faculty of Health Studies University of Mostar \\ ${ }^{3}$ The Pope John XXIII Community Association, Vrgorac, Republic of Croatia \\ ${ }^{4}$ Clinic for Oncology University Clinical Hospital Mostar \\ ${ }^{5}$ Faculty of Health Studies University of Sarajevo \\ 88000 Mostar, Bosnia and Herzegovina
}

\begin{abstract}
Juvenile delinquency points to the existence of adverse social circumstances in which children grow up, and it requires a very complex intervention directed at a number of factors that cause such a phenomenon. Due to insufficient development and sensitivity in this stage of growing up, a young person's development may be directed in an asocial or antisocial direction, going all the way to a criminal form of behavior. A juvenile experimenter is a person who has not been satisfied with life for a long time before they start taking addictive substances. The causes can be different: from loneliness, introversion, unattainable goals, boredom, frustration due to disappointment, or rejection in society. In addition, people who enter the world of addiction usually do not have family in the true sense of the word. It is often not easy to recognize the difference between "normal, " common changes in adolescence, such as mood swings and defying parents and teachers and signs of substance abuse. There are a number of signs of substance abuse in young people, the most important of which is change, that is, it is important to pay attention to any significant changes in physical appearance, personality, attitudes, or behavior. Over the past decades, therapeutic communities have been trying to provide an answer to the phenomena and problems related to substance abuse. All users of the therapeutic community have behavioral problems of various forms and intensities as well as a certain degree of educational neglect. Psychotherapy and rehabilitation are the purpose of the therapeutic community. Without adequate psychotherapy and sociotherapy, juvenile users would become frequent users of health services.
\end{abstract}

Key words: juvenile experimenters; psychoactive substances; therapeutic community

Correspondence:

Professor Dragan Babić. MD, PhD

E-mail: dragan.babic@fzs.sum.ba 